\title{
The bamA gene for anaerobic ring fission is widely distributed in the environment
}

\author{
Abigail W. Porter and Lily Y. Young* \\ Department of Environmental Science, School of Biological and Environmental Sciences, Rutgers University, New Brunswick, NJ, USA
}

\section{Edited by: \\ Amy V. Callaghan, University of \\ Oklahoma, USA}

Reviewed by:

Rachel Narehood Austin, Bates

College, USA

Lisa Gieg, University of Calgary, Canada

\section{*Correspondence:}

Lily Y. Young, Department of Environmental Science, School of Biological and Environmental Sciences, Rutgers University, 59 Dudley Road, New Brunswick, NJ 08901, USA

e-mail: lyoung@aesop.rutgers.edu
Benzoyl-CoA is the signature central metabolite associated with the anaerobic metabolism of a diverse range of compounds such as humic acid, lignin, amino acids, and industrial chemicals. Aromatic chemicals with different upstream degradation pathways all funnel into the downstream benzoyl-CoA pathway. Different genes encoding enzymes of the benzoyl-CoA pathway could be used as biomarkers for the anaerobic benzoyl-CoA pathway, however, the ring opening hydrolase, encoded by the bamA gene, is ideal because it is detected under a range of respiratory conditions, including under denitrifying, ironreducing, sulfate-reducing, and fermentative conditions. This work evaluated DNA samples from six diverse environments for the presence of the bamA gene, and had positive results for every sample. Individual bamA gene clones from these sites were compared to published genome sequences. The clone sequences were distributed amongst the genome sequences, although there were clone sequences from two of the analyzed sites that formed a unique clade. Clone sequences were then grouped by site and analyzed with a functional operational taxonomic unit based clustering program to compare the bamA gene diversity of these sites to that of several locations reported in the literature. The results showed that the sequence diversity of the sites separated into two clusters, but there was no clear trend that could be related to the site characteristics. Interestingly, two pristine freshwater sites formed a subgroup within one of the larger clusters. Thus far the bamA gene has only been examined within the context of contaminated environments, however, this study demonstrates that the bamA gene is also detected in uncontaminated sites. The widespread presence of the bamA gene in diverse environments suggests that the anaerobic benzoyl-CoA pathway plays an important role in the global carbon cycle that has thus far been understudied.

Keywords: anaerobic benzoyl-CoA pathway, bamA gene, 6-oxocylcohex-1-ene-1-carbonyl-CoA hydrolase, monoaromatic degradation, anaerobic hydrocarbon biodegradation

\section{INTRODUCTION}

Aromatic compounds are commonly found in the environment as components in petroleum, industrial contaminants, amino acids, or as humic acids and lignins. Due to the stability of the aromatic ring, these chemicals can be recalcitrant in the environment. Under aerobic conditions, molecular oxygen is incorporated into the aromatic structure by oxygenase enzymes. In the absence of oxygen, therefore, anaerobes have had to evolve different strategies in order to attack these aromatic rings and utilize the available carbon. While anaerobic monoaromatic compound degradation can be initiated in a number of different ways, the signature central metabolite for these pathways is benzoyl-CoA. Under anaerobic conditions, benzoyl-CoA degradation involves an initial systematic reduction of the benzene ring (Figure 1, structures II and III), followed by the hydrolysis of 6-oxocyclohex-1-ene-1-carbonyl-CoA (Figure 1, structure IV) to 3-hydroxypimelyl-CoA (Figure 1, structure V) by 6-oxocyclohex1-ene-1-carbonyl-CoA hydrolase. This latter enzyme is encoded by the $b a m A$ gene and its homologs oah and $b z d Y$, which were previously described in Thauera aromatica (Laempe et al., 1999) and Azoarcus strain CIB (López Barragán et al., 2004), respectively.
These enzymes have the same function, but differ in their genetic nomenclature.

In contrast to the benzoyl-CoA reductase, which differs in obligate and facultative anaerobes (Boll and Fuchs, 1995; Peters et al., 2004; Hosoda et al., 2005; Song and Ward, 2005; Wischgoll etal., 2005), the bamA gene has been reported to be present in isolates growing under a range of redox conditions (Butler et al., 2007; McInerney et al., 2007; Kuntze et al., 2008; for review, see Carmona et al., 2009). Since regions of the bamA gene are highly conserved in a variety of different organisms that are known to utilize the benzoyl-CoA pathway, it is an ideal candidate for use as a molecular biomarker for anaerobic aromatic hydrocarbon biodegradation (Kuntze et al., 2008). In addition, focusing on the bamA gene has the further benefit of indicating that the aromatic ring has been anaerobically cleaved, whereas the upstream reactions do not confer ring fission information.

Reports in the literature have suggested the potential usefulness of using a genetic biomarker based on the benzoyl-CoA pathway for benzene, toluene, and xylene (BTX) or other aromatic contaminants (Hosoda et al., 2005; Song and Ward, 2005; Kuntze et al., 


\section{Thauera aromatica \\ Azoarcus sp. $C l B$ \\ Geobacter}

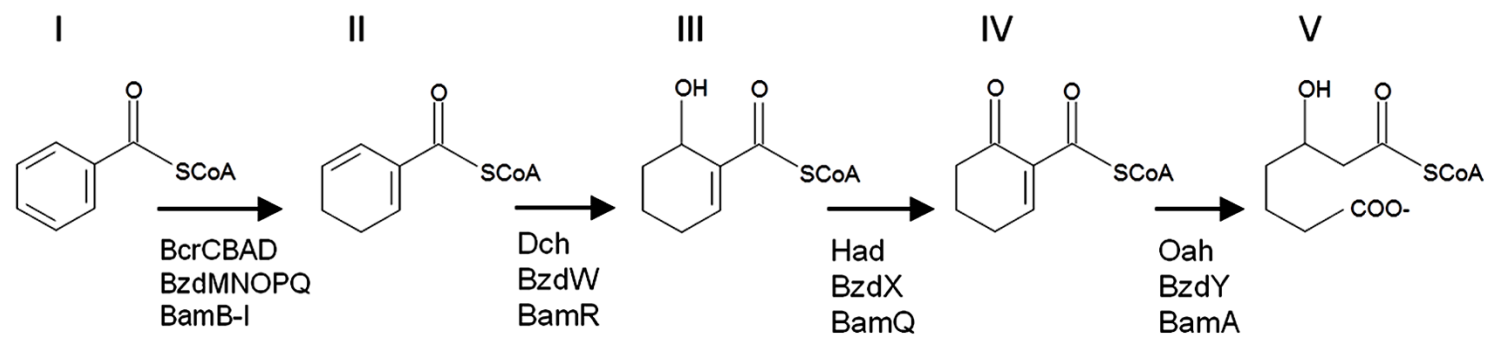

FIGURE 1 | A comparison of the benzoyl-CoA downstream metabolic pathways. Benzoyl-CoA (I) is dearomatized to cyclohexa1,5-diene-1-carbonyl-CoA (II). For Thauera, Azoarcus, and Geobacter the metabolites include 6-hydroxycyclohex-1-ene-1-carbonyl-CoA (III),
6-oxocyclohex-1-ene-1-carbonyl-CoA (IV), and result in 3-hydroxypimelylCoA (V). The corresponding enzymes are indicated below the arrows in the pathway. The pathway is modified from Carmona etal. (2009).
2011; Staats et al., 2011; Li etal., 2012; Sun etal., 2013) yet this pathway is not exclusive to contaminants. There are other aromatic compounds that are found in or released into the environment, including vanillin, $p$-cresol, phenol, aniline, and phenylalanine that are also metabolized via benzoyl-CoA (Harwood et al., 1998).

The bamA gene has thus far been examined only in the context of BTX contamination. It has been used as a molecular biomarker in the laboratory to examine the functional microbial diversity in $p$-xylene degrading marine enrichments (Higashioka et al., 2011), in benzoate- and toluene-degrading denitrifying freshwater enrichments (Li et al., 2012), and in sulfatereducing, denitrifying, and methanogenic toluene-degrading microcosms (Sun et al., 2013). While the bamA gene has been identified in some aromatic compound-degrading isolates, there are a very limited number of studies in which the bamA gene has been used as an environmental biomarker. These include environmental surveys of benzene-contaminated aquifer samples (Kuntze et al., 2011), benzene-contaminated landfill leachate (Staats et al., 2011), and crude oil-contaminated mangrove sediment (Andrade et al., 2012).

The bamA gene has not yet been widely detected in the environment because it has only been evaluated under very limited conditions. We hypothesize that since the bamA gene is specific for a common anaerobic pathway that is would also be key to the downstream metabolism of other types of aromatic compounds, including naturally occurring substrates, and thus be present in uncontaminated sites. This study used culture-independent techniques to examine the bamA gene diversity in DNA extracts from a range of environments and habitats, both with and without aromatic hydrocarbon contaminants, to examine the range of environments in which this gene could be detected as a proxy for the presence of the anaerobic benzoyl-CoA pathway.

\section{MATERIALS AND METHODS DNA EXTRACTIONS}

DNA was extracted from a variety of environments and sample types as described in Table 1. Specifically, DNA was extracted from $0.5 \mathrm{~g}$ sediment samples from sites in New Jersey, USA, and from $1 \mathrm{~g}$ of estuarine and marine sediments from Massachusetts, USA, using a PowerSoil DNA Extraction Kit (Mo Bio Laboratories, Carlsbad, CA) as per the manufacturer's instructions. Approximately $300 \mathrm{ml}$ groundwater samples from Six Mile Run and Crosswicks Creek were filtered through a $0.45 \mu \mathrm{m}$ filter, which was cut into six pieces and extracted using an UltraClean Soil DNA Extraction Kit (Mo Bio Laboratories) with modifications to the manufacturer's instructions as previously described (Barringer et al., 2010).

A conserved 300 base pair region of the bamA gene was targeted with PCR primers BamA SP9F (5' CAG TAC AAY TCC TAC ACV ACB G $3^{\prime}$ ) and BamA ASP1R (5' CMA TGC CGA TYT CCT GRC $\left.3^{\prime}\right)$ as previously described by Kuntze et al. (2008). Each $20 \mu \mathrm{l}$ reaction included $10 \mathrm{mg}$ bovine serum albumin (New England Biolabs, Ipswich, MA, USA), 40 pmol forward and reverse primers, $0.5 \mathrm{mM}$ $\mathrm{MgCl}_{2}, 0.2 \mathrm{mM}$ dNTPs, and $1 \mathrm{U}$ REDTaq DNA polymerase. The reaction conditions were $5 \mathrm{~min}$ at $94^{\circ} \mathrm{C}$, followed by 35 cycles of denaturation at $94^{\circ} \mathrm{C}$ for $30 \mathrm{~s}$, annealing at $59^{\circ} \mathrm{C}$ for $45 \mathrm{~s}$, and elongation at $72^{\circ} \mathrm{C}$ for $60 \mathrm{~s}$, and concluded at $72^{\circ} \mathrm{C}$ for $10 \mathrm{~min}$. All reaction components were from Sigma-Aldrich (St. Louis, MO, USA) unless otherwise indicated.

An arsenic-reducing isolate, Strain MPA-C3, was used as a negative control in the PCR assay. This strain was isolated in our laboratory and had demonstrated anaerobic benzoate-degrading activity, although genome analysis has shown that it does not contain a bamA homolog (Mumford et al., 2013). Strain MPA-C3 was grown in anaerobic freshwater minimal medium (Mumford et al., 2012) with $2 \mathrm{mM} \mathrm{NaH}_{2} \mathrm{AsO}_{4}$ as the terminal electron acceptor and $2 \mathrm{mM}$ sodium acetate as the electron donor. DNA was extracted from $1 \mathrm{ml}$ of $\log$ phase culture using the Mo Bio UltraClean DNA extraction kit, according to the manufacturer's instruction (Mumford et al., 2013).

The bamA gene diversity was further explored in DNA samples from Six Mile Run, Crosswicks Creek, anaerobic digester sludge, and a peat bog by cloning the gene into pGEM-T Easy (Promega, Madison, WI, USA). The Eel Pond and Wild Harbor 
Table 1 | Sites that have tested positive for the bamA gene grouped by the states in which the sites are located.

\begin{tabular}{|c|c|c|c|c|}
\hline Location & Sample type & Site description & $\begin{array}{l}\text { Available electron } \\
\text { acceptors }\end{array}$ & Reference \\
\hline \multicolumn{5}{|l|}{ New Jersey } \\
\hline Crosswicks Creek & Groundwater & Agricultural impact & $\mathrm{Fe}^{3+}$ & Barringer et al. (2010) \\
\hline Joint Meetings of Essex and & Digester sludge & Anaerobic digester & $\mathrm{CO}_{2}$ & Crawford et al. (1995) \\
\hline \multicolumn{5}{|l|}{ Union Counties Wastewater } \\
\hline \multicolumn{5}{|l|}{ Treatment Facility } \\
\hline Mashipacong Bogs Preserve & Sediment & Pristine peat bog & $\mathrm{CO}_{2}$ & This study \\
\hline Six Mile Run & Groundwater & No contamination & $\mathrm{Fe}^{3+}$ & This study \\
\hline \multicolumn{5}{|l|}{ Massachusetts } \\
\hline Eel Pond & Sediment & $\begin{array}{l}\text { Estuarine harbor with } \\
\text { frequent boat activity }\end{array}$ & $\mathrm{SO}_{4}^{2-}$ & This study \\
\hline \multirow[t]{2}{*}{ Wild Harbor } & Sediment & Historic petroleum & $\mathrm{SO}_{4}^{2-}$ & Teal et al. (1978); \\
\hline & & contamination & & Culbertson et al. (2007) \\
\hline
\end{tabular}

The type of sample used in the DNA extraction is indicated, as is the site description which includes potential chemical inputs.

bamA gene PCR products were cloned into an Invitrogen TOPO TA cloning vector (Life Technologies, Grand Island, NY, USA). We randomly selected 38 Eel Pond, 42 Wild Harbor, 8 Crosswicks Creek, 6 Six Mile Run, 6 anaerobic digester, and 13 peat bog clones for nucleotide sequencing (Genewiz, Plainfield, NJ, USA).

\section{PREDICTED AMINO ACID SEQUENCE ANALYSIS}

Predicted amino acid sequences were aligned with ClustalX (Larkin et al., 2007) with BamA hydrolase amino acid sequences from genome sequences and biochemically characterized isolates that have demonstrated anaerobic aromatic hydrocarbon degradation activity. Using ClustalX, we generated a bootstrapped neighbor-joined tree, using 1000 iterations, with methyl-6ketocyclohex-1-ene-1-carbonyl-CoA hydrolase (accession number $\mathrm{CCH} 23022.1$ ) as the outgroup.

Functional operational taxonomic unit (OTU) analyses with the Mothur software package (Schloss et al., 2009) were used to compare site-dependent diversity. The analysis included the clones described above with sequences that had been deposited in GenBank from environmental analyses of 192 clones from Banisveld Landfill (Staats et al., 2011), 6 clones from Hansemann Aquifer (Kuntze et al., 2011), and 9 clones from Gneisenau Aquifer (Kuntze et al., 2011).

\section{NUCLEOTIDE SEQUENCES}

Nucleotide sequences were deposited in GenBank under accession numbers KF170933-KF171005.

\section{RESULTS}

All the DNA extracts from the diverse environmental habitats listed in Table 1 tested positive for the bamA gene. These sites included Crosswicks Creek and Six Mile Run, both of which are uncontaminated, iron rich environments, as well as methanogenic sites including sediment from a pristine bog and sludge from an anaerobic digester. Additionally, two petroleum-contaminated sites Wild Harbor and Eel Pond, which are marine and estuarine, respectively, also contained the bamA gene. We cloned and sequenced random clones from these environments.

To compare these new bamA gene sequences with those previously reported in the literature, we constructed a neighborjoined tree of predicted amino acid sequences from characterized anaerobic aromatic hydrocarbon-degrading isolates and genome sequences, in addition to our environmental clones, as shown in Figure 2. There were three major clades. Clade-1 grouped the BamA amino acid sequences from Rhodomicrobium vannielii with the previously established grouping of Geobacter/Magnetospirillum/Thauera (Staats et al., 2011). More specifically, this clade also included the Oah amino acid sequence from $T$. aromatica (accession number CAA12245), which clustered closely with sequences from two other Thauera isolates. The T. aromatica Oah amino acid sequence shared $82 \%$ identity with the Geobacter bemidjiensis Bem BamA amino acid sequence (accession number YP_002138257) over the 100 residue region analyzed in this study. As with the sequences from Thauera isolates, the BamA amino acid sequences from Geobacter genomes clustered together to form a separate grouping within Clade-1, although this grouping also included sequences from our Crosswicks Creek and Six Mile Run groundwater samples (Figure 2, Clade-1).

Interestingly, we found that Clade-2 (Figure 2) was almost exclusively composed of clones from marine environments Eel Pond and Wild Harbor, with a single clone sequence from the peat bog DNA extract. The sequences in Clade-2 did not cluster with any known characterized isolates or genome sequences, although this may be due to the limited number of BamA hydrolase sequences available. Wild Harbor clone sequences were found exclusively in Clades 2 and 3, whereas the clones from Eel Pond were distributed throughout the dendrogram.

The third clade contained the Syntrophus and Azoarcus groups (Clade-3A and Clade-3B, respectively). The Azoarcus group included the Azoarcus strain CIB BzdY (accession number AAQ08817) amino acid sequence, which also clustered closely with the BamA amino acid sequence from other Azoarcus isolates 


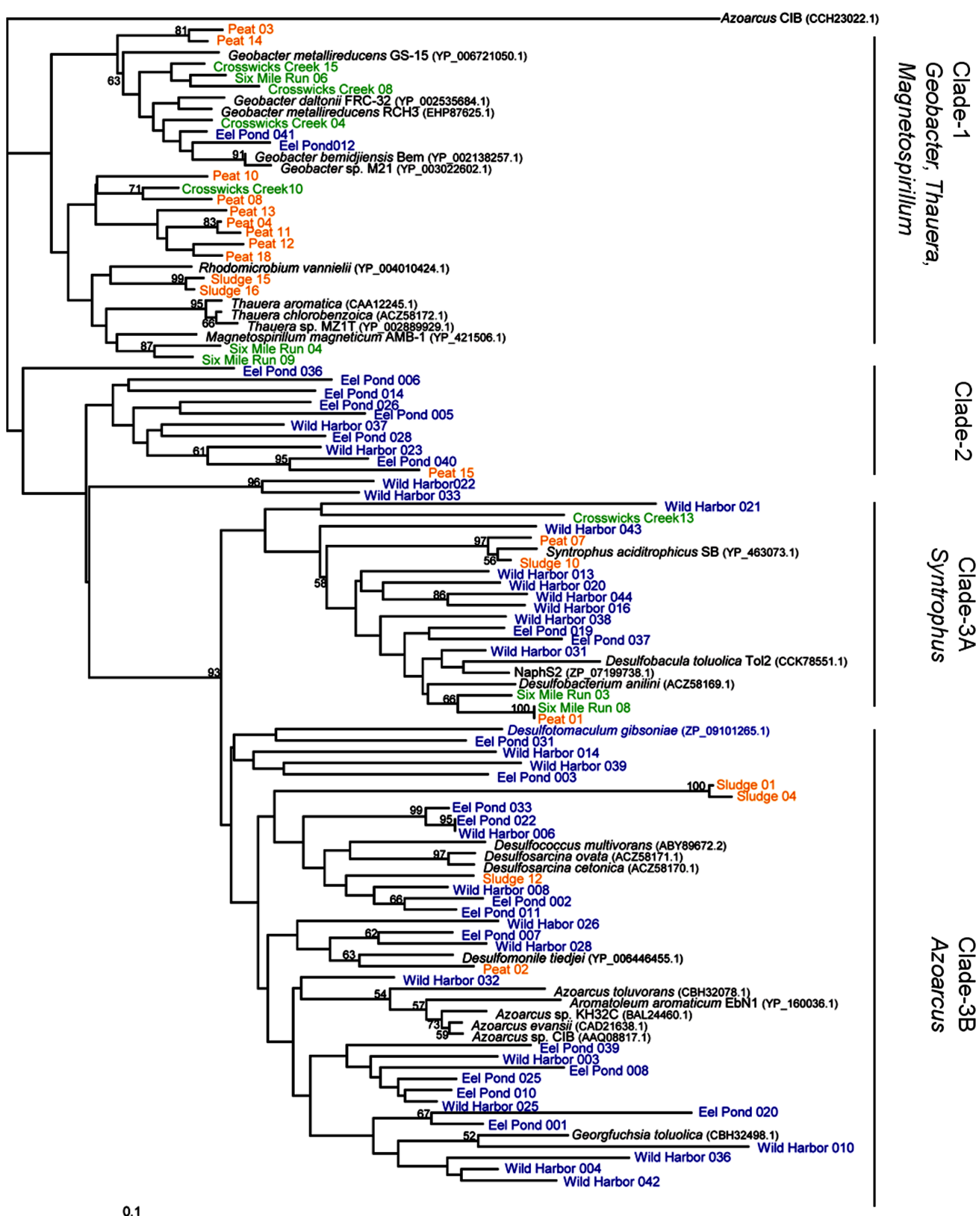

FIGURE 2 | BamA amino acid sequence from characterized isolates, genome sequences, and environmental clones. This is a neighbor-joining tree based on a 97 amino acid sequence alignment and rooted to Azoarcus sp. CIB methyl-6-ketocyclohex-1-ene-1-carbonyl-CoA hydrolase. Bootstrap values are given for 1000 replicate trees, and the values greater than $50 \%$ are indicated. Clones in blue indicate marine sediment DNA extracts (Eel Pond and Wild Harbor), green indicates groundwater samples
(Crosswicks Creek and Six Mile Run), and orange represents methanogenic sites (anaerobic digester and peat bog). Clade-1 contains genome sequences from Geobacter, Magnetospirillum, and Thauera sp. Clade-2 is unique to this study and only contains sequences from Eel Pond and Wild Harbor. Clade-3 has representatives from the Syntrophus (Clade-3A) and Azoarcus (Clade-3B) isolates, along with a several sulfate-reducing microorganisms. 
(Figure 2). The G. bemidjiensis Bem BamA sequence from above and the Azoarcus strain CIB BzdY amino acid sequence shared $70 \%$ identity for the 100 residue region analyzed in this study, which further illustrates the differences between clades. Clade-3 also included a number sequences from sulfate-reducing organisms, such as Desulfobacterium anilini, Desulfobacula toluolica tol2, and NaphS2, that were distributed in both Clade-3A and Clade-3B. Wild Harbor and Eel Pond clones were present in both Clade-3A and Clade-3B as well, as were clones from the anaerobic digester and peat bog DNA samples. The BamA hydrolase sequences from Crosswicks Creek and Six Mile Run groundwater samples were found only in Clade-3A.

We then used a different approach to examine the total bamA gene diversity within each site. In addition to our clone sequences, we also included sequence data from published environmental studies of Hansemann Aquifer and Gneisenau Aquifer, two benzene-contaminated freshwater locations, and Banisveld Landfill leachate, which was also a freshwater site contaminated with BTX chemicals (Kuntze etal., 2011; Staats etal., 2011). The diversity within each site was compared utilizing a functional OTU-based cluster analysis of the predicted amino acid sequences described above using Mothur software (Schloss et al., 2009). All of the sequences used here were from environmental DNA extracts and were not from laboratory cultures. Figure 3 illustrates the differences in diversity across the different sites and shows that the sites were divided into two groups. This data set cannot be compared with the data set used in Figure 2 in which individual sequences are compared to each other, as Figure 3 shows the relationship between

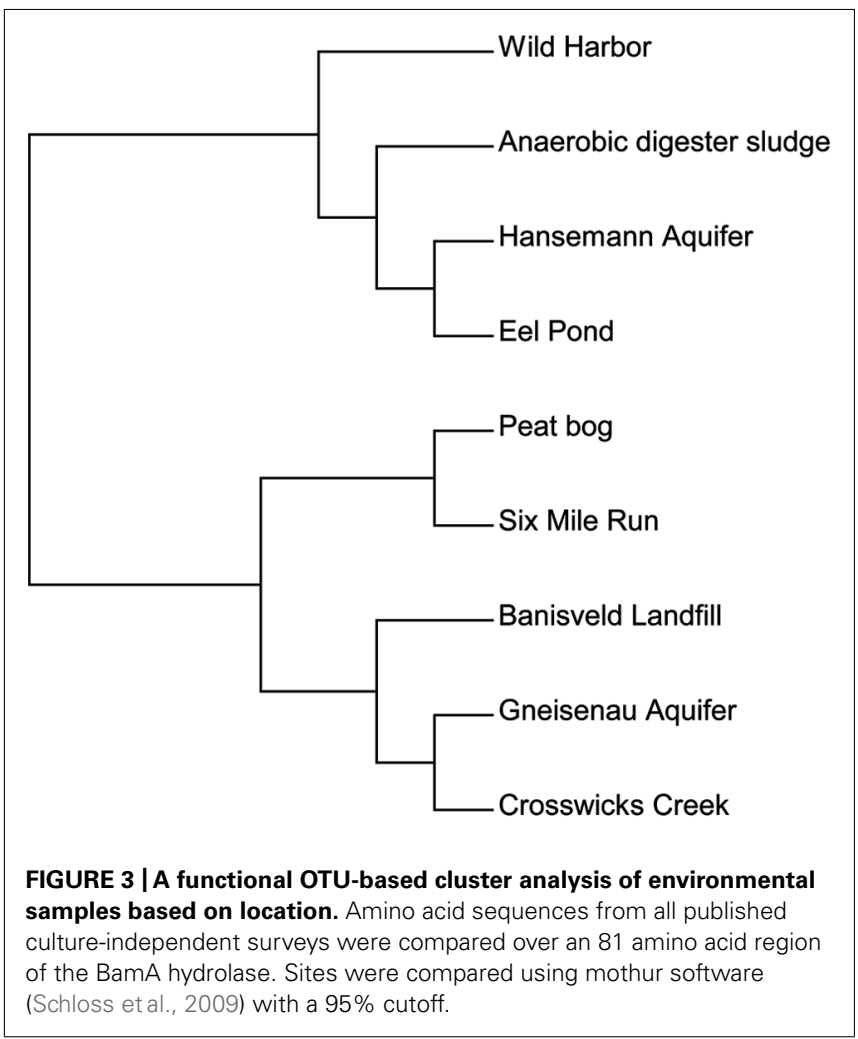

sites based on the diversity of the total sequences from each site.

The first group in Figure 3 contained one cluster of BamA hydrolase sequences from sites that included Wild Harbor, anaerobic digester sludge, Hansemann Aquifer, and Eel Pond. Both Wild Harbor and Eel Pond were sites that have had long-term petroleum contamination, while the Hansemann Aquifer had benzene contamination (Kuntze et al., 2011). The anaerobic digester sludge likely contained other types of aromatic compounds and was not limited to petroleum hydrocarbon contamination. The second group was further divided into two different clusters. The first cluster grouped the total sequences from the peat bog and Six Mile Run groundwater clones together, both of which are clean sites and neither of which have petroleum contamination. Interestingly, these two sites are distinct from the second clustering of sequences from Banisveld Landfill leachate, the Gneisenau Aquifer, and Crosswicks Creek, although Gneisenau Aquifer and Crosswicks Creek shared more total sequence similarity to each other than to Banisveld Landfill sequences. While the Banisveld Landfill and Gneisenau Aquifer were reported to have benzene contamination (Kuntze et al., 2011; Staats et al., 2011), Crosswicks Creek was influenced by agricultural activity (Barringer et al., 2010). Based on our analysis of a limited number of clones from environmental samples, there is evidence of bamA gene diversity in the environment. Although there does not appear to be a clear pattern with respect to the total sequence diversity at the site level that can be attributed to the type of possible organic substrates at the site, it is interesting that the sequences from the peat bog and Six Mile Run, both uncontaminated freshwater sites, clustered separately.

\section{DISCUSSION}

Our analysis of the individual BamA hydrolase amino acid sequence diversity is based upon environmental clones from our laboratory and from the limited number of characterized anaerobic aromatic hydrocarbon-degrading isolates. We did not include other environmental clones or enrichment culture sequences from other studies in Figure 2, as there was no clear association between the BamA amino acid sequence and metabolic activity from these complex samples. The results suggest that to some degree there is an association between some individual BamA hydrolase amino acid sequences and the sample site characteristics. For example, Crosswicks Creek clones are found mainly in Clade-1, which is in agreement with published work that detected measurable iron at the site and identified 16S rRNA gene clones with high similarity to Geobacter sp. Ply1 (Mumford et al., 2012). The peat bog and anaerobic digester clone sequences originated from methanogenic environments and are predominately found in Clade-1 (Figure 2). There are sequences, nonetheless, from these clones that are also found in Clade- 3 and cluster near Syntrophus aciditrophicus, a fermenting benzoate-degrading organism (McInerney et al., 2007). Syntrophus-like organisms have been previously identified in anaerobic digester sludge (Shin et al., 2010).

The majority of the Eel Pond and Wild Harbor sequences are in Clade-2 and Clade-3 (see Figure 2). In addition, Clade-3A and Clade-3B both contain BamA hydrolase sequences from genome sequences of sulfate-reducing microorganisms. The clustering of 
sequences from Eel Pond and Wild Harbor is not unexpected given that they are both coastal marine sites with abundant sulfate that would be found in seawater, and thus support sulfate reducers. The wider distribution of the Eel Pond sequences (Clade-1,-2, and -3), however, differ from the somewhat more narrow distribution of Wild Harbor sequences. Sun et al. (2013) suggested a correlation between the bamA gene sequence and the terminal electron acceptor that was supplied in their microcosm study. That does appear to be the case for the BamA hydrolase sequences from isolates, since the sequences from a particular genus clustered together as previously reported (Kuntze et al., 2008, 2011; Staats etal., 2011). Given the small number of BamA hydrolase sequences available from isolated organisms with available genomes, however, it is difficult to say with confidence that the clone sequences are derived from a specific group within our samples.

In addition to examining the individual clone sequences, we completed a different analysis in which the sequences were grouped by site and the differences in total BamA hydrolase amino acid sequence diversity were examined to see if there was a trend between the study sites and the BamA hydrolase diversity. We included published environmental sequences, although we chose to focus only on the sites with publicly available sequences that did not originate from laboratory cultures (Kuntze et al., 2011; Staats et al., 2011). While there have been studies that examined bamA gene diversity in enrichments or microcosms, the culturing process would have favored specific organisms that were able to utilize the exogenous substrate and thus would not provide an accurate picture of the bamA gene sequences that were present at the site from which the inocula came (Higashioka et al., 2011; Li et al., 2012; Sun et al., 2013). Our intent was to study BamA hydrolase diversity in the natural habitat without culturing or enrichment. The results of site-based diversity comparisons suggest that there were not differences in diversity with respect to type of sites and potentially available organic substrates. For example, both Eel Pond and Wild Harbor are marine sites with historical petroleum contamination. While the total sequences from these two associated together in the same large clustering, the Eel Pond sequence diversity was more similar to that of the benzene-contaminated freshwater Gneisenau Aquifer than to Wild Harbor sequences. Similarly, benzenecontaminated freshwater sites (Banisveld Landfill, Gneisenau Aquifer, and Hansemann Aquifer) were present in both clusters. In contrast, it is interesting that the total sequences from the peat bog and Six Mile Run, both uncontaminated freshwater sites, appear to cluster separately from the other sites. It should be noted, however, that the data presented here are from a limited number of clones in addition to only three sites in the literature from which data were available. The number of available sequences was less than 50 for all of our sites, the Gneisenau Aquifer, and the Hansemann Aquifer (Kuntze etal., 2011), although there were nearly 200 sequences from the Banisveld Landfill (Staats et al., 2011). Expanding the number of sample sites and increasing the sequence coverage with next generation sequencing techniques could potentially yield a more complete assessment of $\operatorname{bam} A$ gene diversity in the environment by capturing the less abundant sequences that might be overlooked in cloning experiments.
A large number of naturally occurring aromatic compounds, including amino acids, humic acid, plant phenolics, and lignin metabolites, are metabolized through the anaerobic benzoyl-CoA pathway, therefore the benzoyl-CoA pathway must play an important role in global anaerobic aromatic hydrocarbon metabolism. We detected the bamA gene in petroleum-contaminated marine sediments, uncontaminated groundwater, anaerobic digester sludge, and peat bog sediment, suggesting that the benzoyl-CoA pathway is common in the environment. Our findings are in agreement with a previous study (Sun et al., 2013) that detected the bamA gene in toluene amended microcosms from diverse inocula, including contaminated sediment and soil, anaerobic digester sludge, aerobic digester sludge, and uncontaminated soil. More specifically, the data reported here demonstrates that the BamA hydrolase is a common feature for the downstream metabolism of the key benzoyl-CoA pathway in anaerobic environments. This, however, does not necessarily relate to contaminant presence, but rather could be the contribution of natural aromatic inputs such as lignin and humic acid. For example, lignin metabolites identified in methanogenic enrichment cultures include cinnamic, vanillic, syringic, and ferulic acids (Colberg and Young, 1985), which would also be metabolized through the benzoyl-CoA pathway. Since the bamA gene has not yet been studied in the context of natural aromatic substrates, future work should utilize a quantitative approach, such as qPCR, to elucidate the naturally occurring abundance of the bamA gene in the environment.

The bamA gene is a biomarker for the anaerobic benzoylCoA pathway, and more broadly anaerobic aromatic hydrocarbon degradation, that we detected in both contaminated and pristine environments. In addition, the bamA gene could be used as a tool for examining sites that contain chemicals with either unknown or multiple mechanisms by which the substrate is anaerobically transformed to benzoyl-CoA. There is great diversity in the mechanisms used in the initial steps of anaerobic aromatic compound degradation that occur prior to benzoyl-CoA formation. For example, L-phenylalanine degradation requires an amino transferase to form phenylpyruvate, which further undergoes a series of steps including decarboxylation, and results in the ultimate formation of benzoyl-CoA (Schneider et al., 1997). In contrast, it has been widely reported that toluene degradation occurs through a fumarate addition mechanism, which results in benzylsuccinate as an intermediate prior to benzoyl-CoA formation (Evans et al., 1992; Biegert et al., 1996). On the other hand, the activation mechanism for anaerobic benzene degradation is less clear as three different mechanisms have been reported. One is methylation to form toluene, which is then metabolized via fumarate addition to benzylsuccinate (Ulrich et al., 2005). Secondly, benzene can undergo hydroxylation to form phenol, which can be further transformed to benzoate and subsequently benzoyl-CoA (Caldwell and Suflita, 2000; Chakraborty and Coates, 2005). Finally, direct carboxylation of benzene to benzoate has also been reported (Phelps et al., 2001; Kunapuli etal., 2008; Abu Laban et al., 2010). As a result, the bamA gene has been targeted, and consistently detected, in benzene-contaminated sites (Kuntze et al., 2011; Staats et al., 2011; Andrade et al., 2012). The bamA gene has demonstrated usefulness when used in conjunction with biomarkers for other genes in the benzoyl-CoA pathway (Kuntze et al., 2011) or with 
molecular probes for specific degradation steps that occur prior to benzoyl-CoA formation, such as the bssA gene which is key in toluene degradation (Staats et al., 2011; Andrade et al., 2012; Sun et al., 2013).

The anaerobic degradation of aromatic hydrocarbons, however, is more important than just with respect to contaminants. The cycling of carbon in anoxic environments is critical to the global carbon cycle but it receives less attention than in its oxic counterpart. To better utilize the bamA gene as a biomarker for anaerobic aromatic compound degradation through the benzoylCoA pathway, however, a more comprehensive set of data are needed for anaerobic degradation of naturally occurring aromatic compounds such as plant phenolics, humics, and lignin. Whether

\section{REFERENCES}

Abu Laban, N., Selesi, D., Rattei, T., Tischler, P., and Meckenstock, R. U. (2010). Identification of enzymes involved in anaerobic benzene degradation by a strictly anaerobic iron-reducing enrichment culture. Environ. Microbiol. 12, 27832796.

Andrade, L. L., Leite, D., Ferreira, E., Ferreira, L., Paula, G. R., Maguire, M., et al. (2012). Microbial diversity and anaerobic hydrocarbon degradation potential in an oil-contaminated mangrove sediment. BMC Microbiol. 12:186. doi: 10.1186/1471-2180-12186

Barringer, J. L., Mumford, A., Young, L. Y., Reilly, P. A., Bonin, J. L., and Rosman, R. (2010). Pathways for arsenic from sediments to groundwater to streams: biogeochemical processes in the Inner Coastal Plain, New Jersey, USA. Water Res. 44, 5532-5544. doi: 10.1016/j.watres.2010.05.047

Biegert, T., Fuchs, G., and Heider, J. (1996). Evidence that anaerobic oxidation of toluene in the denitrifying bacterium Thauera aromatica is initiated by formation of benzylsuccinate from toluene and fumarate. Eur. J. Biochem. 238, 661-668. doi: 10.1111/j.1432-1033.1996.0661w.x

Boll, M., and Fuchs, G. (1995). Benzoyl-coenzyme A reductase (dearomatizing), a key enzyme of anaerobic aromatic metabolism. Eur. J. Biochem. 234, 921-933. doi: 10.1111/j.1432-1033.1995.921_a.x

Butler, J. E., He, Q., Nevin, K. P., He, Z., Zhou, J., and Lovley, D. R. (2007). Genomic and microarray analysis of aromatics degradation in Geobacter metallireducens and comparison to a Geobacter isolate from a contaminated field site. BMC Genomics 8:180. doi: 10.1186/1471-2164-8-180

Caldwell, M. E., and Suflita, J. M. (2000). Detection of phenol and benzoate as intermediates of anaerobic benzene biodegradation under different terminal electron-accepting conditions. Environ. Sci. Technol. 34 1216-1220. doi: 10.1021/es990849j

Carmona, M., Zamarro, M. T. Blázquez, B., Durante-Rodríguez, G., Juárez, J. F., Valderrama, J. A., et al. (2009). Anaerobic catabolism of aromatic compounds: a genetic and genomic view. Microbiol. Mol. Biol. Rev. 73, 71-133. doi: 10.1128/MMBR.00021-08

Chakraborty, R., and Coates, J. D. (2005). Hydroxylation and carboxylation - two crucial steps of anaerobic benzene degradation by Dechloromonas strain RCB. Appl. Environ. Microbiol. 71, 54275432. doi: 10.1128/AEM.71.9.54275432.2005

Colberg, P. J., and Young, L. Y. (1985). Aromatic and volatile acid intermediates observed during anaerobic metabolism of lignin-derived oligomers. Appl. Environ. Microbiol. 49, 350-358.

Crawford, D. W., Bonnevie, N. L., and Wenning, R. J. (1995). Sources of pollution and sediment contamination in Newark Bay, New Jersey. Ecotoxicol. Environ. Saf. 30, 85-100. doi: 10.1006/eesa.1995.1010

Culbertson, J. B., Valiela, I., Peacock, E. E., Reddy, C. M., Carter, A., and VanderKruik, R. (2007). Long-term biological effects of petroleum residues on fiddler crabs in salt marshes. Mar. Pollut. Bull. 54, 955-962. doi: 10.1016/j.marpolbul.2007.02.015

Evans, P. J., Ling, W., Goldschmidt, B., Ritter, E. R., and Young, L. Y. (1992). Metabolites formed during anaerobic transformation of toluene and $o$-xylene and their proposed relationship to the initial steps of toluene mineralization. Appl. Environ. Microbiol. 58, 496-501.

Harwood, C. S., Burchhardt, G., Herrmann, H., and Fuchs, G. (1998). Anaerobic metabolism of aromatic compounds via the benzoyl-CoA pathway. FEMS Microbiol. Rev.

there are $b a m A$ gene differences for anthropogenic or natural aromatic substrates has yet to be determined. Nonetheless, evidence thus far, indicates that the bamA gene in the benzoyl-CoA pathway is central to anaerobic aromatic ring fission in a variety of environments and by extension is a key component in the global carbon cycle.

\section{ACKNOWLEDGMENTS}

We wish to thank Sarah Wolfson for contributing Eel Pond and Wild Harbor bamA gene clone sequences, Adam Mumford for providing DNA extracts and sediment samples, Maria Rivera for anaerobic digester samples, and Katie Della Terza for peat bog samples.

22, 439-458. doi: 10.1111/j.15746976.1998.tb00380.x

Higashioka, Y., Kojima, H., and Fukui, M. (2011). Temperature-dependent differences in community structure of bacteria involved in degradation of petroleum hydrocarbons under sulfate-reducing conditions. $J$. Appl. Microbiol. 110, 314-322. doi 10.1111/j.1365-2672.2010.04886.x

Hosoda, A., Kasai, Y., Hamamura, N., Takahata, Y., and Watanabe, K. (2005). Development of a PCR method for the detection and quantification of benzoyl-CoA reductase genes and its application to monitored natural attenuation. Biodegradation 16, 591-601. doi: 10.1007/s10532-005-0826-5

Kunapuli, U., Griebler, C., Beller, H. R., and Meckenstock, R. U. (2008). Identification of intermediates formed during anaerobic benzene degradation by an iron-reducing enrichment culture. Environ. Microbiol. 10, 1703-1712. doi: 10.1111/j.14622920.2008.01588.X

Kuntze, K., Shinoda, Y., Moutakki, H., McInerney, M. J., Vogt, C., Richnow, H.-H., et al. (2008). 6-Oxocyclohex1-ene-1-carbonyl-coenzyme A hydrolases from obligately anaerobic bacteria: characterization and identification of its gene as a functional marker for aromatic compounds degrading anaerobes. Environ. Microbiol. 10, 1547-1556. doi: 10.1111/j. 1462-2920.2008.01570.x

Kuntze, K., Vogt, C., Richnow, H.-H., and Boll, M. (2011) Combined application of PCRbased functional assays for the detection of aromatic compounddegrading anaerobes. Appl. Environ. Microbiol. 77, 5056-5061. doi: 10.1128/AEM.00335-11

Laempe, D., Jahn, M., and Fuchs, G. (1999). 6-Hydroxycyclohex-1-ene1-carbonyl-CoA dehydrogenase and 6-oxocyclohex-1-ene-1-carbonylCoA hydrolase, enzymes of the
benzoyl-CoA pathway of anaerobic aromatic metabolism in the denitrifying bacterium Thauera aromatica. Eur. J. Biochem. 263, 420-429. doi: 10.1046/j.1432-1327.1999.00504.x

Larkin, M. A., Blackshields, G., Brown, N. P., Chenna, R., McGettigan, P. A., McWilliam, H., et al. (2007). Clustal W and Clustal X version 2.0. Bioinformatics 23, 2947-2948. doi: 10.1093/bioinformatics/btm404

Li, Y.-N., Porter, A. W., Mumford, A., Zhao, X.-H., and Young, L. Y. (2012). Bacterial community structure and bamA gene diversity in anaerobic degradation of toluene and benzoate under denitrifying conditions. J. Appl. Microbiol. 112, 269-279. doi: 10.1111/j.1365-2672.2011.05213.x

López Barragán, M. J., Carmona, M., Zamarro, M. T., Thiele, B., Boll, M., Fuchs, G., et al. (2004). The bzd gene cluster, coding for anaerobic benzoate catabolism, in Azoarcus sp. strain CIB. J. Bacteriol. 186, 5762-5774. doi: 10.1128/JB.186.17.5762-5774.2004

McInerney, M. J., Rohlin, L., Mouttaki, H., Kim, U., Krupp, R. S., Rios-Hernandez, L., et al. (2007). The genome of Syntrophus aciditrophicus: life at the thermodynamic limit of microbial growth. Proc. Natl. Acad. Sci. U.S.A. 104, 7600-7605. doi: 10.1073/pnas.0610456104

Mumford, A. C., Barringer, J. L., Benzel, W. M., Reilly, P. A., and Young, L. Y. (2012). Microbial transformations of arsenic: mobilization from glauconitic sediments to water. Water Res. 46, 2859-2868. doi: 10.1016/j.watres.2012.02.044

Mumford, A. C., Yee, N., and Young, L. Y. (2013). Precipitation of alacranite (As8S9) by a novel As(V)-respiring anaerobe strain MPA-C3. Environ. Microbiol. doi: 10.1111/14622920.12136 [Epub ahead of print]

Peters, F., Rother, M., and Boll, M. (2004). Selenocysteinecontaining proteins in anaerobic benzoate metabolism of 
Desulfococcus multivorans. J. Bacteriol. 186, 2156-2163. doi: 10.1128/JB.186.7.2156-2163.2004

Phelps, C. D., Zhang, X., and Young, L. Y. (2001). Use of stable isotopes to identify benzoate as a metabolite of benzene degradation in a sulphidogenic consortium. Environ. Microbiol. 3, 600-604. doi: 10.1046/j. 1462-2920.2001.00228.x

Schloss, P., Westcott, S., Ryabin, T., Hall, J., Hartmann, M., Hollister, E., et al. (2009). Introducing mothur: open-source, platform-independent, community-supported software for describing and comparing microbial communities. Appl. Environ. Microbiol. 75, 7537-7534. doi: 10.1128/ AEM.01541-09

Schneider, S., Mohamed, M. E., and Fuchs, G. (1997). Anaerobic metabolism of L-phenylalanine via benzoyl-CoA in the denitrifying bacterium Thauera aromatica. Arch. Microbiol. 168, 310-320. doi: 10.1007/s002030050504

Shin, S. G., Lee, S., Lee, C., Hwang, K., and Hwang, S. (2010). Qualitative and quantitative assessment of microbial community in batch anaerobic digestion of secondary sludge. Bioresour. Technol. 101, 94619470. doi: 10.1016/j.biortech.2010. 07.081

Song, B., and Ward, B. B. (2005) Genetic diversity of benzoyl coenzyme A reductase genes detected in denitrifying isolates and estuarine sediment communities. Appl. Environ. Microbiol. 71, 2036-2045. doi: 10.1128/AEM.71.4.2036-2045.2005

Staats, M., Braster, M., and Röling, W. F. M. (2011). Molecular diversity and distribution of aromatic hydrocarbon-degrading anaerobes across a landfill leachate plume. Environ. Microbiol. 13, 1216-1227. doi: 10.1111/j.1462-2920.2010.02421.x

Sun, W., Sun, X., and Cupples, A. M. (2013). Presence, diversity and enumeration of functional genes (bss $A$ and $b a m A$ ) relating to toluene degradation across a range of redox conditions and inoculum sources. Biodegradation doi: 10.1007/s10532013-9651-9654
Teal, J. M., Burns, K., and Farrington, J. (1978). Analyses of aromatic hydrocarbons in intertidal sediments resulting from two spills of No. 2 fuel oil in Buzzards Bay, Massachusetts. J. Fish. Res. Board Can. 35, 510-520. doi: 10.1139/ f78-095

Ulrich, A. C., Beller, H. R., and Edwards, E. A. (2005). Metabolites detected during biodegradation of 13C6-benzene in nitrate-reducing and methanogenic enrichment cultures. Environ. Sci. Technol. 39, 6681-6691. doi: 10.1021/es050 $294 \mathrm{u}$

Wischgoll, S., Heintz, D., Peters, F., Erxleben, A., Sarnighausen, E., Reski, R., et al. (2005). Gene clusters involved in anaerobic benzoate degradation of Geobacter metallireducens. Mol. Microbiol. 58, 1238-1252. doi: 10.1111/j.13652958.2005.04909.x

Conflict of Interest Statement: The authors declare that the research was conducted in the absence of any commercial or financial relationships that could be construed as a potential conflict of interest.

Received: 31 December 2012; accepted: 19 September 2013; published online: 10 October 2013.

Citation: Porter AW and Young LY (2013)

The bamA gene for anaerobic ring fission is widely distributed in the environment. Front. Microbiol. 4:302. doi: 10.3389/ fmicb.2013.00302

This article was submitted to Microbiological Chemistry, a section of the journal Frontiers in Microbiology.

Copyright (c) 2013 Porter and Young. This is an open-access article distributed under the terms of the Creative Commons Attribution License (CC BY). The use, distribution or reproduction in other forums is permitted, provided the original author(s) or licensor are credited and that the original publication in this journal is cited, in accordance with accepted academic practice. No use, distribution or reproduction is permitted which does not comply with these terms. 